Information for citation:

Makhov V. N., Vasilenko A. S., Chebukhanova L. V. Elementy vosstanovitel'nogo pravosudiya v ugolovnom sudoproizvodstve [Elements of Restorative Justice in Criminal Proceedings]. Vestnik Permskogo Universiteta. Juridicheskie Nauki - Perm University Herald. Juridical Sciences. 2017. Issue 35. Pp. 107-121. (In Russ.). DOI: $10.17072 / 1995-4190-2017-35-107-121$.

UDC 343.1

DOI: 10.17072/1995-4190-2017-35-107-121

\title{
ELEMENTS OF RESTORATIVE JUSTICE IN CRIMINAL PROCEEDINGS
}

\section{N. Makhov}

Peoples' Friendship University of Russia (RUDN University)

6, Miklukho-Maklaya st., Moscow, 117198, Russia

ORCID: 0000-0003-3728 -6068

ResearcherID: M-3497-2016

e-mail: tatamimax@mail.ru

\section{A. S. Vasilenko}

Peoples' Friendship University of Russia (RUDN University)

6, Miklukho-Maklaya st., Moscow, 117198, Russia

ORCID: 0000-0003-4029-8502

ResearcherID: N-6839-2016

e-mail: kholoimova@mail.ru

\section{V. Chebukhanova}

Peoples' Friendship University of Russia (RUDN University) 6, Miklukho-Maklaya st., Moscow, 117198, Russia

ORCID: 0000-0001-5642-6674

ResearcherID: P-1966-2015

e-mail: 1.chebukhanova@mail.ru

Introduction: the article is aimed at the analysis of reputable and qualified public members involvement in the sphere of criminal proceedings and in the resolution of criminal conflicts through mediation under control of the court in foreign countries, especially those with the Anglo-Saxon law system. In the United States and other common law countries, restorative justice has demonstrated some good results. Restorative justice considers an offence not only as violation of the law, but primarily the victim's rights violation. It also sees it as a wrongdoing, stating that the offence was committed not so much against public order and the State, but as trespass to the person. Restorative justice is aimed not only at punishing the offender and compensating for damages caused to the victim, but also, to a certain extent, at the offender's correction. It is generally recognized that incarceration does not correct the accused, and it can aggravate the vices of the individual in many cases. Restorative justice is able to avoid such issues. Not accidentally, the application of restorative justice programs, including these in the criminal process, is recommended by a number of international legal norms, especially in resolution of criminal cases against minors. In our country, the attitude to juvenile justice is ambiguous. However, this circumstance does not give the grounds to ignore the practice of the USA and other countries and gradually implement the elements of restorative justice that are acceptable to our criminal procedure. Purpose: to analyze the formation of the restorative justice paradigm, as well as the current practice of restorative justice programs in the countries of the

(C) Makhov V. N., Vasilenko A. S., Chebukhanova L. V., 2017 
Anglo-Saxon legal system, to identify some positive practices and substantiate the proposals for the consolidation of restorative justice programs in criminal procedure of the Russian Federation. Methods: there were used the dialectical, historical, comparative legal, system-structural, and logical-legal methods. Results: It is concluded that there is necessity for legislative consolidation of the possibility of the restorative justice programs use in criminal procedure of the Russian Federation. It is proposed to introduce relevant amendments to the Criminal Procedure Code of the Russian Federation.

Keywords: restorative justice; juvenile justice; mediation; family conference; conciliation; mediated agreement

\author{
Information in Russian
}

\title{
ЭЛЕМЕНТЫ ВОССТАНОВИТЕЛЬНОГО ПРАВОСУДИЯ В УГОЛОВНОМ СУДОПРОИЗВОДСТВЕ
}

\section{B. H. Maxoв}

Доктор юридических наук, профессор кафедры уголовного права, уголовного процесса и криминалистики Российский университет дружбы народов 117198, Россия, г. Москва, ул. Миклухо-Маклая, 6 ORCID: 0000-0003-3728-6068

ResearcherID: M-3497-2016

e-mail: tatamimax@mail.ru

\section{А. С. Василенко}

Кандидат юридических наук, доцент кафедры уголовного права, уголовного процесса и криминалистики Российский университет дружбы народов 117198, Россия, г. Москва, ул. Миклухо-Маклая, 6 ORCID: 0000-0003-4029-8502

ResearcherID: N-6839-2016

e-mail: kholoimova@mail.ru

\section{Л. В. Чебуханова}

Магистр права, экономист юридического института Российский университет дружбы народов 117198, Россия, г. Москва, ул. Миклухо-Маклая, 6 ORCID: 0000-0001-5642-6674

ResearcherID: P-1966-2015

e-mail: 1.chebukhanova@mail.ru

Введение: статья посвящена анализу опыта зарубежных, прежде всего англосаксонских, стран по вовлечению в сферу уголовного прочесса авторитетных, квалифицированных представителей общественности, в разрешение конфликтов преступного характера под контролем суда путем медиации. В США и других странах англосаксонского права восстановительное правосудие дает хорошие результаты. Восстановительное правосудие видит в преступлении не только нарушение закона, но в первую очередь нарушение прав жертвы, считает, что преступление совершено не столько против общественного порядка и государства, сколько против личности. Восстановительное правосудие ставит своей целью не только наказать преступника и возместить ущерб, причиненный им жертве преступления, но и, в определенной мере, исправить преступника. Общепризнанно, что лишение свободы не исправляет обвиняемого, а во многих случаях 
усугубляет пороки личности. Восстановительное правосудие позволяет избежать таких ошибок. Не случайно применение программ восстановительного правосудия, в том числе в уголовном проиессе, рекомендовано рядом международно-правовых документов, прежде всего при разрешении уголовных дел в отношении несовершеннолетних. В нашей стране отношение к ювенальной юстиции неоднозначно. Но это обстоятельство не дает основания игнорировать зарубежный опыт США и других стран и поэтапно заимствовать элементы восстановительного правосудия, приемлемые для нашего уголовного прочесса. Цель: проанализировать становление парадигмы восстановительного правосудия, а также сложившейся практики применения программ восстановительного правосудия в странах англосаксонского права, выявить положстельный опыт и обосновать предложения по закреплению программ восстановительного правосудия в уголовнопроиессуальном законодательстве Российской Федераџии. Методы: при написании статьи использовались диалектический, исторический, сравнительно-правовой, системно-структурный и логико-юридический методы. Результаты: сделан вывод о необходимости законодательного закрепления возможности использования программы восстановительного правосудия в уголовном судопроизводстве Российской Федерачии. Сделано предложение по внесению соответствующих изменений в Уголовно-процессуальный кодекс Российской Федерации.

Ключевые слова: восстановительное правосудие; ювенальная юстиция; медиация; семейные конференции; примирительная процедура; медиативное соглашение

\section{Formation of the Restorative Justice Paradigm}

In 1970 John Griffiths, an American professor of criminal procedure proposed a new concept of criminal proceedings - the "family model" [22, pp. 373-380] (restorative justice), which has become a counterweight not only to the views of G. Packer at his "double" concept, but also, in a certain sense, it has become a counterweight to the adversarial principle of the criminal proceedings in the United States [11, p. 82; 12, p. 45]. Restorative justice emphasizes the value of equal interest in the resolution of the case by both the victims and the criminals, but at the same time it does not focus on the importance of enforcement. It also aims at the harm caused to individuals and relationships, rather than at the offense itself. The restorative justice model includes a number of restorative programs for victims, society and offenders [29, pp. 38-41].

Restorative justice is also identified by an American scholar Beyzmor Gordon as one of the three paradigms for juvenile justice [2, p. 76]. The first paradigm is punitive. Its purpose is punishment to the extent of the offense. The punitive paradigm itself least sets the goal of rehabilitation. Moreover, this paradigm extends the value of formal hostility of the parties, determining guilt and the appropriate consequences of the verdict [30, p. 443].

The punitive approach was changed by the paradigm of individualization of treatment (parens pa- triae, or as it is called in Europe, "a model of social services"). According to this concept, punishment is not the main response to crime, as the crime itself is "a sign of disturbed processes of socialization" [34; 35 , p. 230]. Public organizations, government and education institutions have increasingly tried to solve this problem, though their activities have become less efficient due to more formalization occurred.

As a result, decision-makers in the area of juvenile justice disagree on the punishment and the best ways of protecting public safety 32,$58 ; 31$, p. 357; 25, pp. 137-172]. They often disguised punishment under individualization of treatment [28; 27 , p. 127], mixed purposes of punishment and public safety and often considered the application of sanctions as an alternative to the individual approach, rather than the primary component of the juvenile justice system [26, p. 159; 19, 18].

In addition, there are some new legal acts that regulate the activities of juvenile justice. In the new legislation less attention was paid to rehabilitation of the offender and the powers of the prosecuting authorities were expanded. All this has led to the use of more and more harsh penalties. However, no positive trends related to crime rate were observed.

Society was gradually coming to the opinion that severe punishment is an appropriate response to a crime (which is the main idea of the punitive approach). But time has shown that the severity of the punishment, too, does not lead to the desired positive results. And the model of social 
services has already outdated and appeared as a reaction to the crime which only benefits the criminal. This paradigm does not make any attempts to explain to the offender that (s)he has done damage to someone and needs to take certain measures for reparation, improving the situation and be liable for the consequences of the harm caused by the crime.

Experts who study the function of punishment noted that there are several effective ways of making an offender take responsibility for their crimes and respond to the legitimate needs of society. In addition, these methods are aimed at adopting some positive values and bringing to the criminals' minds that they have offended others, and that criminal behavior is unacceptable. Thus, the society has come to restorative justice, that is, to the implementation of the third paradigm.

It is easy to trace the process of the paradigm change in the context of the historical development of the criminal procedure in the USA, which was formed following the example of the criminal procedure in England, with a certain characteristic of Private Prosecution Institute. As a result, firstly, the victim had a wide range of rights American criminal case. By the end of the 18th century in the USA public charge had begun to replace private one and the role of the state in the criminal justice system had increased significantly. The role of the victim in the investigation of crimes decreased to such an extent that by the early 19th century the victims of a crime were not granted the right to claim compensation for damages from the offender in criminal trial. The crime came to be regarded as an encroachment not on a specific person, but on society as a whole.

In the 20th century, the vector of criminal justice development in the United States shifted toward providing procedural rights to the accused, almost oblivious to the needs of victims of crime. $[8$, p. $10 ; 9$, p. 23] Since the early 70 -ies, due to the spread of the ideas of restorative justice, the government drew attention to a crime victim in the criminal procedure in the USA.

Restorative justice, unlike the punitive approach considers crime not only as breaking the law, but firstly as the violation of the victim's rights. It considers that the crime is committed not only against the public order and the state, but primarily against the victim. Restorative justice puts the main goal in taking criminal liability for the act, of reparation to the victim, reconciliation of the of- fender and the victim and social rehabilitation of the offender in society [2, p. 84].

It is more persuasive to conclude on insolvency of a punitive approach to tackling crime. In recent decades, the idea of restorative justice has spread beyond the USA and now it is gaining greater reputation [5]. The focus here is put not on punishment, but on the reconciliation of the offender with the victim and reparation [6, p. 43].

The original meaning of the restorative justice paradigm, the idea of a reaction to the crimes, originates from the "traditions of non judicial understanding of justice, when the stumbled admonition or criminal conflicts resolution were carried out in the framework of small local communities through reconciliation or agreement between the parties on the basis of positive values". The main idea of restorative justice is not new. For example, its basic principles are compatible with the traditions of native American, Hawaiian, Canadian indigenous population, aborigines in Australia and Maori in New Zealand. These principles are also comparable to the values underlined in almost all the world's religions [33, pp. 4-5].

As L. V. Golovko notes, in the 70-ies of the 20th century there was a crisis of the punitive approach to solving crime [3, p. 103]. Restorative justice as an alternative is gaining credibility worldwide. The focus here is put not on the punishment, but on the reconciliation of the offender with the victim and on the reparation for the damages [6, p. 44].

\section{Restorative Justice Programs Used in Criminal Proceedings in the Countries of Anglo-Saxon Law}

In North Carolina, there is an interesting program for mediation in the district criminal court. This program provides mediation in the court and works as an alternative to judicial investigation, but not to the criminal procedure as a whole.

Such program is enshrined in the norms of North Carolina General Statutes, and the Supreme Court adopted the Supreme Court Rules to enforce these norms ${ }^{1}$. It is clearly stated in $\S 7 \mathrm{~A}-38.3 \mathrm{D}$ (a) North Carolina General Statutes that the General Assembly considers the implementation of mediation in district criminal courts as activities in the

\footnotetext{
${ }^{1}$ Rules Implementing Mediation in Matters Pending in District Criminal Court. Available at: http://www.aoc.state.nc.us/ www/public/html/pdf/Dispute_Resolution/DistrictCriminal Court.pdf (accessed 01.12.2016).
} 
public interest. For this purpose, in district courts organizations practicing restorative justice programs created the certified mediation program. Judges and district attorneys should encourage mediation for any criminal cases, if they see the benefits of such procedures.

In addition to the above documents, in this state there are "Rules implementing mediation in matters pending in district criminal court".

In accordance with these rules, the court guided by inner conviction and by external factors such as the willingness of parties to participate in the mediation program; the refusal of a judicial investigation does not violate the rights of third parties involved in the process; the opportunity in this specific case of the termination of the criminal case behind reconciliation of the parties, etc. may recommend to the parties to participate in this program.

The court encourages mediation and conciliation to achieve agreement as soon as possible.

After the case materials with the indictment document are received by the court, the district attorney (and sometimes the judge) shall inform the parties about the possibility of participation in the program of mediation. If the victim and the offender agree to participate in this program, mediation can be held directly at the courthouse. If the case involves several defendants or victims, at the court discretion, these persons can be united to participate in mediation.

If the parties have agreed to participate in the mediation, the court will in writing or orally notify them on the following conditions:

1. The deadline set by the court for mediation;

2. The name of the mediator or the name of the community mediation center;

3. The claim for payment by offender a criminal duty of $\$ 60$ for the implementation of mediation services.

In $\S 7 \mathrm{~A}-38.3 \mathrm{D}(\mathrm{m})$ North Carolina General Statutes states that by agreement, all or any portion of the fee may be paid by a person other than the defendant. In § 7A-38.7 (b) North Carolina General Statutes states that the community mediation center shall require proof that the defendant has paid the dispute resolution fee and shall attach the receipt to the dismissal form. Then the court sends the case materials to the community mediation center or a particular mediator.
North Carolina establishes the right of parties to apply to the court or community mediation center for the replacement of the mediator that guarantees the protection of participants from possible bribery of the mediator of one party.

If all parties have expressed their desire to participate in the mediation procedure and there all formalities are eliminated, the mediation can take place at community mediation center, in the courthouse or any other place, according to the agreement between the mediator and the parties [24].

Before the procedure, the mediator is obliged to explain to the parties the stages of mediation and its principles, the rights and obligations of the parties and the features of the mediated agreement.

In accordance with the "Rules implementing mediation in matters pending in district criminal court", the participants who agreed to mediation must be physically present at it. But there are exceptions to this rule: by agreement of the parties and the mediator or by the court the person may be allowed to participate in mediation by telephone or to be represented by a lawyer or a representative.

In general, "Rules implementing mediation in matters pending in district criminal court" permit the presence at the mediation procedure and the participation of the parents and guardians of minors (in this case mediation becomes similar to a family conference), the lawyer (consultation are allowed before, during and after the mediation, as well as monitoring compliance with agreements) and third parties (in this case mediation becomes like circles of justice [16, pp. 315-318]) if the mediator believes their presence will help achieve the goals of mediation. But the mediator has the right to restrict the participation of such persons at any time as soon as (s)he considers that their participation has negative impact on the mediation process.

Thus, the consolidation in the state's legislation of the mediation does not mean that the mediator cannot use other techniques of restorative justice in the process of reconciliation of the parties.

Mediation procedure itself takes place in conditions of confidentiality. The Rules mentioned above contain direct prohibition on the stenographic, audio or video recording by all participants of the mediation. It is emphasized that this prohibition applies to record with the consent of the parties. 
In addition to the principle of confidentiality the mediator is given the witness privilege in the matters relating to mediation. The meaning of this privilege is as follows: if after mediation the parties have reconciled and the mediated agreement is not concluded, the case is returned to court and normal criminal procedure continues. It should be mentioned that if the materials are sent from the court to the mediator, district attorney may delay prosecution of those actions so that the mediation may take place (N.C.G.S. § 7A-38.3D(b)). After returning the criminal case to the court and resuming the process in according with the North Carolina General Statutes $\S 7 \mathrm{~A}-38.3 \mathrm{D}(\mathrm{k})$ - no mediator shall be compelled to testify or produce evidence concerning statements made and conduct occurring in or related to a mediation in any proceeding in the same action for any purpose.

However, this rule has several exceptions. The mediator may report to law enforcement personnel on any statement made or on the conduct occurring during the mediation process that threatens or threatened the safety of any person or property. As the mediator may derogate from the principle of confidentiality if it is satisfied in the process of mediation that the adult family members violate the rights of minors. In addition, the court may compel the disclosure of any evidence arising from the mediation if the court determines that the introduction of the evidence is necessary to the proper administration of justice and the evidence cannot be obtained from any other source (N.C.G.S. § 7A$38.3 \mathrm{D}(\mathrm{k})(4))$.

The ideal result of mediation shall be a mediated agreement which contains all the terms agreed upon by the parties. An obligatory condition is the written form of the agreement and signatures of both parties. In North Carolina this agreement enters into force as soon as it is signed by the parties. In Idaho, the mediated agreement is treated more seriously, and for entry into force it must be approved by the court $(18.1(8) / 12.1(8))$.

For today, Victim-Offender Mediation program has spread beyond America and now is successfully working in Canada, England and New Zealand and in other countries. Typically, the program is carried out by private non-profit or public organization, which works in close collaboration with a local court [21].
Since the 70-ies, in addition to mediation there were started many programs which can be called restorative ones. Here are some of these programs.

Family Group Conferencing program is based on the old traditions of dispute resolution of the Maori tribes in New Zealand. Today, the family conferences are used for most of the crimes committed by juvenile offenders.

In its modern form, the program has been enshrined in national legislation in New Zealand since 1989. Thus, from all the considered models of reconciliation in criminal proceedings in Anglo-Saxon countries this model is most completely regulated by legal acts.

This reconciliation program is currently used in the same way in other countries: Australia (in a modified form), the USA and Canada. In these countries, a family conference is used for such crimes as theft, arson, vandalism, drug offenses and others. In New Zealand, this program is applied for the crimes of any severity, except very serious ones [17].

This model of restorative justice is interesting because the conciliation procedure is fully controlled by law enforcement. The police involved in the process of reconciliation are present at every meeting of participants and have the same rights as everybody else. In addition, the process is monitored by the court for youth which can find a teenager guilty and to transfer the case to the district court for sentencing. Thus, as it is rightly pointed out by L. M. Karnozov, "it reaches the necessary balance between community ways of conflict resolution and the necessary legal safeguards provided by the court" [7, p. 229].

Family conferences have a wider range of participants than Victim-Offender Mediation program. They are attended by the offender, members of his/her family, the victim and members of his/her family's lawyer for youth, and a police officer. Family conference is convened by court for youth coordinator [30].

The mission of the family conference is to work out an action plan for the offender to remedy. In addition, the family conference decides the question of the necessity of sanctions application by the court.

The court almost always adopts the plan developed at the family conference. But it may use a broad range of sanctions, up to deprivation of liberty 
for a term up to 5 years, even if the family conference has not recommended its use. This is particularly important when the prescribed plan of correction is not performed. Thus, the court acts as a "final stage", if the plan is violated, and as a "filter" for clearly not satisfactory recommendations $[10$, p. 53].

This form of restorative justice is optimal for juvenile offenders due to the important role of family in their lives [30]. In 1989 New Zealand adopted the "Children, Young Persons, and Their Families Act" that formalized the procedure of reconciliation in the legislation. As mentioned above, the program is used in other Anglo-Saxon countries, for example, in the Australian state of New South Wales. This procedure is also regulated by "Young Offenders Act" (1997). The program used in New South Wales was positively evaluated by the New South Wales Bureau of Crime Statistics and Research.

The practice of family conferences can be applied to almost all crimes committed by adolescents, although in practice it is used only in sufficiently serious cases (except those where the law does not provide the possibility of its application). Less significant cases are dealt with help of the police. Family conferences differ from the above Victim-Offender Mediation program and VictimOffender Reconciliation Programs in that they involve a greater number of the society members in the discussion of the crime, recognize a broader range of victims of crime and focus on the participation of the families of the offenders' representatives [24; 37, pp. 137-145].

Family conferences were first introduced in 1991 in Australia as a part of a police initiative ("Model Wagga" of conference holding in New South Wales). The police conferences were also established in the Australian Capital Territory. In other States and the Northern territories the conferences were held on the basis of the judicial system. Conferences in the field of juvenile delinquency were legislatively approved in 1993-1994 in South and Western Australia. The conferences there were held without the police professionals [49, pp. 2145]. Later conferences were legally approved in New South Wales and Queensland (juvenile of- fenders); the practice of conferencing is also used in the schools of Queensland. The model of conferences is integrated in other countries including Canada, the US and the UK [23, p. 128].

\section{Basis for the Restorative Justice Formation in the Russian Federation}

Today there is a worldwide trend of humanization of criminal legislation and practice of its application. In our study, we found that foreign states (on the basis of Anglo-Saxon law countries analysis) tend to move away from punitive, repressive criminal proceedings. The main direction of such countries is restorative justice.

In the Russian Federation state leaders repeatedly declare that Russia is on the path of criminal law humanization. The restorative justice programs have already been used in our criminal procedure without violating the Criminal Procedure Code of the Russian Federation norms and focusing on the norms of international law.

Let us start with the fact that in 2004 in the city of Taganrog in the Rostov region there was created the first "model juvenile court". Then, in 2005 and 2006, two model juvenile courts were opened in the city of Shakhty. Model juvenile courts may be located in a separate building and can occupy some place in the building of the city (or district) court. A distinctive feature of such courts is a special room for a psychologist and a mediation room. The courtroom in such courts is not equipped with bars, but equipped with special furniture such as a semicircular table, behind which the participants including the judge sit in the trial.

The special features of the emerging model of juvenile system in the Rostov region include active use of the elements of restorative justice, which consists of the application of conciliatory procedures carried out with the mutual consent of the victim and the juvenile offender [36].

The judges of the Rostov region periodically report to the Presidium of the Judges Council of the Russian Federation on the results of model juvenile courts. One of the Resolutions of the Presidium states: "...Despite the absence of the special judicial legislation on juvenile courts in Russia they 
create its elements in law enforcement practice on their own initiative, promoting enhancement of legal proceedings for minors and increasing rehabilitation in the judgements. Considerable decrease in recurrent crime of minors testifies to efficiency of juvenile technologies.

The 2008 generalization by the Supreme Court of the Russian Federation of the practice of introducing juvenile technologies in the courts of general jurisdiction showed that juvenile technologies at the regional level create the conditions for the organization of a truly effective juvenile justice system in the Russian Federation. In order to improve the efficiency and quality of juvenile justice, measures should be taken to ensure uniformity of the judicial practice of juvenile application technologies, to develop mechanisms for interaction of courts with the bodies of the system of neglect and juvenile delinquency, prevention, and legislation in this field..."1.

The words "juvenile technologies" are not highlighted incidentally. In fact, for the first time the term was used by the Supreme Court of the Russian Federation in "The Reference of introduction of juvenile technologies in courts of law" in 2008. Today it is applied quite often in spite of the fact that according to the working group on representation of Judicial Council of the Russian Federation on creation and development of juvenile justice in the justice system of the Russian Federation there is no legal definition of the concept "juvenile technologies".

In the Reference on maintaining courts of subjects of the Russian Federation the information on use of juvenile technologies by courts of general jurisdiction, the working group on representation of Judicial Council of the Russian Federation attempts to give definition of this term. So, according to the reference, juvenile technologies are the special organization of justice concerning minors in the conflict with the penal statute founded on comprehen-

\footnotetext{
${ }^{1}$ On Judicial Practice of Application of the Legislation Regulating Peculiarities of Criminal Liability and Punishment of Minors: Resolution of the Plenum of the Supreme Court of the Russian Federation of February 01, 2011 No. 1. Rossiyskaya gazeta. 11 Feb. 2011.
}

sive awareness of age features of minors, application of special rehabilitation programs (methods, techniques) eliminating further possible delinquent behavior of minors ${ }^{2}$.

Holding conciliatory procedures of restorative justice as well as private injunction (individual juvenile rehabilitation plan is issued in this way in Russia) are the elements of juvenile technologies, and these technologies are applied in the courts of 52 subjects of the Russian Federation ${ }^{3}$, and also in the explored countries of Anglo-Saxon law.

Thus, the establishment of restorative justice in relation to minors has occurred. It should be noted that in the analyzed countries, mediation and other programs of restorative justice were primarily used only for minors. And only then fears that mediation cannot be effective and achieve its goals with respect to adult criminals have been dispelled. Today, adult offenders can also participate in mediation in these countries.

\section{Overview of the Elements of Restorative Justice Practices in Criminal Proceedings in Russia}

In the case of the use of restorative justice programs within the framework of juvenile technologies, they remain unchanged at the pre-trial stages. After receiving information about the crime and its verification, the criminal proceedings start, if there are the grounds for this. Then a preliminary investigation is conducted, and the criminal case is sent to the court.

However, the normal course of proceedings can be changed in court. Due to the lack of legislative consolidation of the restorative programs (which are an integral part of juvenile technologies), the court does not have a clear algorithm for this practice of applying to minors, therefore, each court has its own traditional procedural features. But in general, in the practice of applying

\footnotetext{
${ }^{2}$ Information on the Results of Generalizing Information of the RF Subjects' Courts on Using Juvenile Technologies by the General Jurisdiction Courts, Prepared by the Working Group under the Council of Judges of the Russian Federation on Establishment and Development of the Juvenile Justice System of the Russian Federation. Available at: http://www.juvenilejustice.ru/ documents/rabgr/monit_reg/monreg (accessed 01.12.2016).

${ }^{3}$ Ibidem.
} 
restorative programs (within the framework of juvenile technologies), some general sequence of actions can be found out.

As a rule, in courts where juvenile technologies are applied, the post of a judicial assistant with the functions of a social worker (or with the functions of a social educator) is created. This specialist works together with judges and is exclusively engaged in cases of minors.

When a criminal case is sent to the court, the assistants create a "social and psychological support card", which lists all available data on the identity of minors. If there is no such position in the prosecution court, it prepares a report on the identity or a social support card with help of any prevention specialist (usually a psychologist or social welfare worker) ${ }^{1}$.

The card will indicate the information received during a conversation with a teenager, his/her parents, the identification of information received from the commission on the affairs of minors, school, neighbors, and from the tests conducted by minors [15].

The card or report on identity is not proof in accordance with the Criminal Procedure Code of the Russian Federation, but the information is examined by the court in the proceedings. Often the drafters of this document are involved to interrogation as experts. Thus, the information contained in the card acquires probative value, and the card itself (or report) is attached to the case materials. This is done in accordance with Articles 73, 74, 84 of the Criminal Procedure Code of the Russian Federation, since this card is considered as the "other document" containing information of importance for establishing the circumstances that characterize the personality of the accused.

Then the judicial assistant sends the necessary materials (application for mediation, social security card, etc.) to the Municipal Reconciliation Service and the Commission for the Affairs of Minors and the protection of their rights (for example, as in the Perm region). At the same time, the assistant sends information letters to the victim, as well as the accused or their legal representatives. This letter informs that a criminal case has been filed and the court cooperates with the mediation service (Mediation Commission etc.). This is done to help the

\footnotetext{
${ }^{1}$ Information on the Results of Generalizing Information of the RF Subjects' Courts on Using Juvenile Technologies by the General Jurisdiction Courts...
}

parties come to the agreement on the compensation of the harm caused. The parties should be notified in the letter that the employees offer mediation services to hold a meeting of the parties. In some regions, such a letter sent to the parties is signed by the Chairperson of the district court.

If the parties agree to a conciliation meeting, the mediation officer (the lead specialist) analyzes all available information and selects the type of mediation program. Then preliminary meetings are held, one of which should ideally end with the conclusion of an agreement. Then, the lead officer makes a report on the results of the mediation program and sends it to the court and to the Commission for the Affairs of Minors and the protection of their rights. The court must receive this report no later than 3 days before the trial [13, p. 31].

There has been similar practice in Moscow. When a criminal case against a juvenile arrives in one of the district courts of Moscow, the judge, on his/her own initiative, guided by his/her inner conviction on the basis of international principles of mediation and restorative justice, can send information about the case to the Perekrestok Center. The specialists of the Center "...focus on the programs of restorative justice..." [14]. These experts analyze the information received and, if possible, organize preliminary meetings with the accused and their legal representative, and then with the victim. This is followed by a joint meeting, according to which the parties can conclude an agreement on mediation.

Further this agreement and the report of the expert are taken to court. The court files these documents with the case and then takes into account the participation in the restorative justice programs as a mitigating factor.

In the practice of the Perekrestok Center and judicial cooperation, there were cases when after the meeting the victim sent an application for dismissing of the criminal case due to the reconciliation of the parties. And the court, in accordance with Article 25 of the Code of Criminal Procedure of the Russian Federation and Article 76 of the Criminal Code of the Russian Federation, dismissed the case due to the reconciliation of the parties.

Thus, the mediator of the Center worked with the seventeen-year-old Yuri who committed an illegal encroachment on the ownership of the car (part 3 
of Article 30, part 1 of Article 166 of the Criminal Code of the Russian Federation). Please note that this is a misdemeanor. Meanwhile, Yuri tried to commit a crime twice, but in both cases that was not possible due to the reasons beyond his control. At first, Yuri managed to escape, in the second case he was arrested. There were found 2 victims.

When the mediator attempted to contact the victims and to offer participation in the rehabilitation program, only one victim agreed. The second person refused to participate.

In the end, full mediation took place between the accused and one of the victims.

However, in court Yuri apologized to the second victim, who accepted it and refused the compensation of the caused damage requirement, considering it as insignificant. Both of the victims petitioned the court to dismiss the criminal case due to reconciliation of the parties. The court granted the motions and dismissed the case [1, pp. 38-43].

In the Rostov region, the application practice is different and all the preparatory work is done by judge assistant with functions of a social worker. $\mathrm{S} /$ he collects all the necessary information about the minor, characterizing the personality and the living conditions of the minor defendant. The judicial assistant together with the bodies and institutions of the state system of neglect and minors offenses prevention, conducts a socio-psychological examination of the defendant, and puts collected information into the card of social support or a report to the court. The assistant conducts conciliation procedures and prepares court recommendations [15].

In the practice of the center of the Ivanovo region "...while preparing a criminal case against a minor a judge sends to the Commission for the Affairs of Minors and Protection of their Rights a resolution on the socio-psychological examination of the adolescent's personality, on the preparation of proposals on the possibility of the court applying educational and rehabilitation measures instead of punitive and repressive ones, on the application of measures of social adaptation of minors in conflict with the law, as well as on the support for the interaction of the court with all the agencies of prevention and public organizations..." This resolution is sent to the psychologist who collects and summarizes information about the social status of the minor and his/her life conditions and education, and establishes contact with the minor and his/her parents (representatives). After that, all received information is reflected in the card of sociopsychological support. Then the psychologist decides on the possibility and necessity of mediation programs. And if s/he finds it possible "...the psychologist organizes a reconciliation meeting at the Mediation commission with the participation of the accused minor, his parents / legal representatives, the victim, enabling the offender to take responsibility for his actions, to compensate the caused harm to the victim, and the victim to get the support, to restore a sense of security and to obtain compensation for material damage and moral injuries. The meeting of the accused and the victim is held only in the case of prerequisites: recognition of the accused of participation in a criminal situation; his/her willingness to make amends for the harm done by their actions; the victim's willingness to meet with the accused. The General condition of mediation programs is the voluntary participation of the parties, which is found out by a psychologist in confidential meetings..."

If the parties reconcile, they sign an agreement, which sets out the terms of the mediation agreement. Then the agreement is sent to court, where it is attached to the criminal case materials and disclosed in trial. The psychologist is involved in trial as an expert. After the end of the proceedings, the Coordination Council on development of juvenile justice monitors compliance with the agreement concluded by the parties ${ }^{1}$.

Describing the practice of restorative programs in the Russian criminal procedure, we consider the ideal model where the parties agree to the mediation meeting. However, it does not always happen.

It should be noted that from time to time, the mediator is faced with such a problem, for example, when the offender sincerely wants to participate in mediation, indemnify and reconcile with the victim, which is not necessarily motivated by the desire to avoid criminal liability, but the victim refuses to participate in mediation.

Regardless of who holds the conciliation meeting, in any case all the records are sent to the judge. It is worth noting that even if the parties have

\footnotetext{
${ }^{1}$ Information on the Results of Generalizing Information of the RF Subjects' Courts on Using Juvenile Technologies by the General Jurisdiction Courts...
} 
reconciled and the defendant has compensated the damage, the court cannot be avoided. Thus, this does not violate the principle of justice only by the court.

As mentioned earlier the court is entitled to attach the file with all documentation obtained after the reconciliation procedure or the documents containing information about the restorative justice program application. Different regions have different practices, and documents have different names. That can be a report to the court on the identity or a card of social support, which are prepared upon receiving the case by a judge assistant, court clerk or court psychologist. Also, depending on the region, these documents may be examined in a court session as materials describing the identity of the defendant. Sometimes information from these documents is disclosed by those who made these documents during interrogation as an expert in court, and in this case, the obtained evidence is entered the court records, and these documents are kept in a criminal case ${ }^{1}$.

In the Perm region, a social profile for a minor defendant is formed, to which mediation agreements signed as a result of the mediation program may be attached. The assistant to judge forms this file.

As a result, the final decision is taken by the court, which according to its internal conviction evaluates the provided information. Analyzing the Resolution of the Plenum of the Supreme Court of the Russian Federation "On judicial practice of legislation application regulating the features of criminal liability and punishment of minors" Professor A. V. Grinenko rightly drew attention to the instruction of the Plenum to discuss in each specific case the possibility of applying to the juvenile the provisions of Articles 75-78 of the Criminal Code of the Russian Federation (including the reconciliation with the victim in misdemeanor cases) and Articles 24-28 of the Criminal Code of the Russian Federation for exemption from criminal liability [4, p. 11]. Thus, the Supreme Court, and members of the judiciary appeal judges pay more attention to possibility of exemption of minors from criminal

\footnotetext{
${ }^{1}$ Children in Conflict with the Law: Analytical Review. Region. Association of Specialists for Support for the Legal and Judicial Reform and Juvenile Justice in the Rostov Region. Rostov-onDon, 2010. Available at: https://refdb.ru/look/2407458-pall.html (accessed 01.12.2016).
}

liability. We believe that legislative consolidation of mediation programs will contribute to the implementation of such recommendations, but the exemption from liability will be linked with extremely important rehabilitation work with the minors.

According to existing practice, the court decision can include the individual rehabilitation plan for a particular minor (there are similarities to New Zealand family conferences, which led to the mandatory component of the offender's plan of action for correction approved by the court). It is adopted in the form of a private court decision (part 4 of Article 29 of the Code of Criminal Procedure of the Russian Federation) as the basis of individual preventive work with juvenile bodies and services of the system of prevention of neglect and juvenile delinquency (an individual program for the rehabilitation of a minor in accordance with Article 6 of the Federal Law No. 120-FZ of June 24, 1999 "On the Basics of the Prevention of Neglect and Juvenile Delinquency").

\section{Conclusion}

In this study, we analyzed the elements of restorative justice programs, the practice which is currently applied in the Russian Federation. An urgent need was identified for the legislative consolidation of the possibility of applying restorative justice programs in criminal procedure of the Russian Federation. In this case, the use of such programs is the most reasonable when the evidence has already been collected. In this case, the use of such programs is the most reasonable when the evidence of criminal case has already been collected. This will protect participants of criminal process from a number of problems that may arise if the parties agree to mediation and it has not been successful. Thus, we propose to apply a restorative program only at the trial stages.

In order to be independent and objective in this situation, the court needs the assistance of an objective, professionally trained mediator, whose mission is reconciliation of the parties. It seems necessary to make the following revision of Article 25 adoption in the Criminal Procedure Code of the Russian Federation on the reconciliation of the parties: "the Court has the right, at the request of the victim or their legal representative to dismiss the criminal case against the person accused of 
committing a crime of minor or medium gravity, in the cases provided by Article 76 of the Criminal Code of the Russian Federation, if, with the assistance of an independent, impartial, professionally trained mediator mandated by the court, that person reconciled with the victim and made amends for his/her harm, or for this purpose an agreement was drawn up as a result of mediation".

\section{References}

1. Balaeva A. V., Zhenodarova E. D., Karnozova L. M. Osnovy gumanitarnoy kompetentnosti sud'i, rassmatrivayushchego ugolovnye dela $v$ otnoshenii nesovershennoletnikh: Metodicheskoe posobie [The Basis of the Humanitarian Competence of a Judge Dealing with Criminal Cases against Minors: Tutorial]. Moscow, 2011. 174 p. (In Russ.).

2. Bazemore G. Tri paradigmy yuvenal'noy yustitsii - Pravosudie po delam nesovershennoletnikh: Perspektivy razvitiya [Three Paradigms of Juvenile Justice - Juvenile Justice: Prospects for Development]. Issue 1. Moscow, 1999. Pp. 67-99. (In Russ.).

3. Golovko L. V. Al'ternativy ugolovnomu presledovaniyu $v$ sovremennom angliyskom prave [Alternatives to Prosecution in the Contemporary English Law]. Pravovedenie - Pravovedenie. 1998. Issue 3. Pp. 101-103 (In Russ.).

4. Grinenko A.V. Vliyanie gumanizatsii ugolovnogo zakonodatel'stva Rossiyskoy Federatsii na ugolovnoe sudoproizvodstvo [The Impact of Humanization of Criminal Legislation of the Russian Federation on Criminal Justice]. Sud'ya - Judge. 2011. Issue 7. Pp. 10-13. (In Russ.).

5. Zehr H. Vosstanovitel'noe pravosudie: novyj vzglyad na prestuplenie i nakazanie [Changing Lenses: a New Focus for Crime and Justice]. Moscow, 1998. Available at: http://sprc.ru/wpcontent/uploads/2012/08/3ep-X.-Восстановительное-правосудие.pdf (accessed 01.12.2016). (In Russ.).

6. Karnozova L., Maksudov R., Flyamer M. Vosstanovitel'noe pravosudie: idei i perspektivy dlya Rossii [Restorative Justice: Ideas and Prospects for Russia]. Rossiyskaya yustitsiya - Russian Justitia. 2000. Issue 11. Pp. 42-44. (In Russ.).

7. Karnozova L. M. Ugolovnaya yustitsiya i grazhdanskoe obshhestvo. Opyt paradigmal'nogo analiza [Criminal Justice and Civil Society. The Experience of Paradigmatic Analysis]. Moscow, 2010. 480 p. (In Russ.).

8. Kukhta K. I., Makhov V. N. Pravovoy status zhertvy prestupleniya (poterpevshego) $v$ ugo- lovnom protsesse SShA [The Legal Status of the Victim in the Criminal Process in the USA]. Moscow, 2008. 216 p. (In Russ.).

9. Kukhta K. I. Pravovoy status zhertvy prestupleniya (poterpevshego) $v$ ugolovnom protsesse SShA: avtoref. diss. kand. yurid. nauk [The Legal Status of the Victim in the Criminal Process in the USA: Synopsis of Cand. jurid. sci. diss.]. Moscow, 2006. 23 p. (In Russ.).

10. McElrea F.W. D. Novozelandskaya model' semeynykh konferentsiy. Pravosudie po delam nesovershennoletnikh: Mirovaya mozaika i perspektivy $v$ Rossii [The New Zealand Model of Family Group Conferencing - Juvenile Justice: Global Mosaic and Prospects in Russia]. Vol. 2. Moscow, 2000. Pp. 40-71. (In Russ).

11. Makhov V. N., Peshkov M. A. "Sostyazatel'nost'” modeley ugolovnogo protsessa SShA ["Contentiousness" of the Models of the USA Criminal Process]. Gosudarstvo i pravo - State and Law. 1999. Issue 12. Pp. 81-87. (In Russ.).

12. Makhov V. N., Peshkov M. A. Yuristy SShA o modelyakh ugolovnogo protsessa [USA Lawyers about Models of the Criminal Process]. Sledovatel' (federal'noe izdanie) - Investigator (Federal Edition). 1999. Issue 6. Pp. 38-48. (In Russ.).

13. Pokrovskaya V.L. Vnedrenie vosstanovitel'nykh tekhnologiy v deyatel'nost' sub"ektov profilaktiki Permskogo kraya: Metodicheskie materialy [Implementing Reconstructive Technologies in the Activity of the Subjects of Prevention in the Perm Region: Educational materials]. Perm, 2009. Pp. 30-34. (In Russ.).

14. Rabota $s$ pravonarusheniyami nesovershennoletnikh [The Work with Juvenile Delinquency]. Available at: http://www.perekrestok.info/ index.php?option $=$ com_content $\&$ view $=$ article $\& \mathrm{id}=224 \&$ Itemid $=224$ (accessed 01.12.2016). (In Russ.).

15. Tkachev V. N. Opytnaya model' yuvenal'noy yustitsii $v$ Rostovskoy oblasti $i$ ee rasprostranenie $v$ regionakh Rossii [The Experimental Model of Juvenile Justice in the Rostov Region and its Distribution in the Regions of Russia]. Available at: http://www.rostoblsud.ru/to_352 4582 (accessed 01.12.2016). (In Russ.).

16. Bazemore G., Schiff M. Community Justice. Restorative Justice: Prospects for a New Social Ecology for Community Corrections. International Journal of Comparative and Applied Criminal Justice. 1996. Issue 20(2). Pp. 311334. (In Eng.).

17. Bazemore G., Umbreit M. Rethinking the Sanctioning Function in Juvenile Court: Retribution 
or Restorative Responses to Youth Crime. Crime and Delinquency. 1995. Issue 41(3). Available at: https://www.researchgate.net/publication/24971 8602_Rethinking_the_Sanctioning_Function_in Juvenile_Court_Retributive_or_Restorative_Response_to_Youth_Crime (accessed 01.12.2016). (In Eng.).

18. Bazemore G., Umbreit M. A Comparison of Four Restorative Conferencing Models. U.S. Department of Justice Office of Justice Programs Office of Juvenile Justice and Delinquency Prevention. February 2001. Available at: https://www.ncjrs.gov/pdffiles1/ojjdp/1847 38.pdf (accessed 01.12.2016) (In Eng.).

19. Braithwaite J. Restorative Justice \& Responsive Regulation. 2002. Oxford University Press, at 249. Available at: http://johnbraithwaite.com/ wp-content/uploads/2016/06/Restorative-Justiceand-Respon.pdf (accessed 01.12.2016). (In Eng.).

20. Feld B. The Punitive Juvenile Court and the Quality of Procedural Justice: Disjunctions between Rhetoric and Reality. Crime \& Delinquency. 1990. Issue 36. Pp. 443-466 (In Eng.).

21. Gehm J. R. Victim-Offender Mediation Programs: An Exploration of Practice and Theoretical Frameworks. Western Criminology Review. 1998. Issue 1(1). Available at: http://wcr.sonoma.edu/vln1/gehm.html. (accessed 01.06.2016). (In Eng.).

22. Griffiths $J$. Ideology in Criminal Procedure or a Third "Model" of the Criminal Process. The Yale Law Journal. 1970. Vol. 79. Pp. 359-417. (In Eng.).

23. Hudson J., Morris A., Maxwell G., Galaway B. Family Group Conferences: Perspectives on Policy and Practice. Monsey, NY: Criminal Justice Press. 1996. 240 p. (In Eng.).

24. Maxwell G., Morris A. Family, Victims and Culture: Youth Justice in New Zealand. Wellington, NZ: Social Policy, 1993. Available at: https://www.msd.govt.nz/documents/about-msdand-our-work/publications-resources/archive/ 1993-family-victims-and-culture.pdf (accessed 01.06.2016). (In Eng.).

25. McAnany P. D., Thompson D., Fogel D. Probation and Justice: Reconsideration of Mission. Cambridge, MA: Oelgeschlager, Gunn \& Hain, 1984. 408 p. (In Eng.).

26. Melton G. Taking Gault Seriously: Toward a New Juvenile Court. Nebraska Law Review. 1989. Issue 68. Pp. 146-181. (In Eng.).

27. Miller J. Lost One Over the Wall; The Massachusetts Experiment in Closing Reform Schools. Columbus, OH: Ohio State University Press, 1991. 279 p. (In Eng.).
28. Restorative Justice: How it Works / Marian Liebmann. Publisher: Jessica Kingsley Publishers. 15 April 2007. 472 p. (In Eng.).

29. Restorative Justice: the Government's Strategy July 2003. Response by Victim Support. Available at: http://www.restorativejustice.org.uk/assets/_ugc/fetch.php?file=c3kp_Restorative_justice_the_governments_strategy_response_of_victi m_support.pdf (accessed 01.06.2016). (In Eng.).

30. Restorative Justice. Available at: http://www. answers.com/topic/restorative-justice (accessed 01.03.2013). (In Eng.).

31. Rothman D. Conscience and Convenience; The Asylum and its Alternatives in Progressive America. New York: HarperCollins, 1980. 469 p. (In Eng.).

32. Schneider A. Deterrence and Juvenile Crime: Results from a National Policy Experiment. New York: Springer-Verlag, 1990. 127 p. (In Eng.).

33. Umbreit M., Zehr H. Agency and Institute of Criminology, Victoria University of Wellington. Family Group Conferences: A Challenge to Victim-Offender Mediation? VOMA Quarterly. Issue 7. 1995-1996. Pp. 4-8. (In Eng.).

34. Umbreit M. S. Restorative Justice through Victim-Offender Mediation: A Multi-Site Assessment. Western Criminology Review. 1998. Issue 1(1). Available at: http://wcr.sonoma.edu/ v1n1/ umbreit.html (accessed 01.03.2013). (In Eng.).

35. Walgrave L. Restorative Justice for Juveniles: Just a Technique or a Fully Fledged Alternative? Howard Journal of Criminal Justice. 1995. Issue 34(3). Pp. 228-249. (In Eng.).

36. Whyt J. How Do You Mediate a Criminal Case? The American Bar Association Criminal Justice Section Newsletter. Vol. 15. Issue 1. Fall 2006. Available at: http://www.americanbar.org/content/dam/aba/publishing/criminal_ju stice_section_newsletter/crimjust_newsletterfall 2006.authcheckdam.pdf (accessed 01.06.2016). (In Eng.).

37. Zehr H. Changing Lenses: A New Focus for Crime and Justice. Scottsdale, PA: Herald Press, 1990. 271 p. (In Eng.).

\section{References in Russian}

1. Балаева А. В., Женодарова Е. Д., Карнозова Л. М. Основы гуманитарной компетентности судьи, рассматривающего уголовные дела в отношении несовершеннолетних: метод. пособие / под ред. Л. М. Карнозовой. М.: ООО «Акварель», 2011. 174 с.

2. Бэйзмор Г. Три парадигмы ювенальной юстиции // Правосудие по делам несовершеннолетних: перспективы развития. М.: МОО 
Центр «Судебно-правовая реформа», 1999. Вып. 1. С. 67-99.

3. Головко Л. В. Альтернативы уголовному преследованию в современном английском праве // Правоведение. 1998. № 3. С. 101-103.

4. Гриненко А. В. Влияние гуманизации уголовного законодательства Российской Федерации на уголовное судопроизводство // Судья. 2011. № 7. С. 10-13.

5. Зер $X$. Восстановительное правосудие: новый взгляд на преступление и наказание. М.: Центр «Судебно-правая реформа», 1998. URL: http://sprc.ru/wp-content/uploads/2012/ 08/Зер-Х.-Восстановительное-правосудие.pdf (дата обращения: 01.12.2016).

6. Карнозова Л., Максудов Р., Флямер М. Восстановительное правосудие: идеи и перспективы для России // Российская юстиция. 2000. № 11. С. 42-44.

7. Карнозова Л. М. Уголовная юстиция и гражданское общество. Опыт парадигмального анализа. М.: Р. Валент, 2010. 480 с.

8. Кухта К. И., Махов В. Н. Правовой статус жертвы преступления (потерпевшего) в уголовном процессе США. М.: Юрлитинформ, $2008.216 \mathrm{c}$.

9. Кухта К. И. Правовой статус жертвы преступления (потерпевшего) в уголовном процессе США: автореф. дис. ... канд. юрид. наук. М., 2006. 23 c.

10. Макэлри Ф. Новозеландская модель семейных конференций // Правосудие по делам несовершеннолетних: Мировая мозаика и перспективы в России: в 2 кн. / под ред. М. Г. Флямера. М.: МОО Центр «Судебноправовая реформа», 2000. Кн. 1. С. 40-71.

11. Махов В.Н., Пешков М. А. «Состязательность» моделей уголовного процесса США // Государство и право. 1999. № 12. С. 81-87.

12. Махов В. Н., Пешков М. А. Юристы США о моделях уголовного процесса. // Следователь (федеральное издание). 1999. № 6. С. $38-48$.

13. Покровская В.Л. Внедрение восстановительных технологий в деятельность субъектов профилактики Пермского края: метод. материалы АНО «Центр социально-психологической помощи населению». Пермь, 2009. C. 30-34.

14. Работа с правонарушениями несовершеннолетних. URL: http://www.perekrestok.info/ index.php?option $=$ com_content $\&$ view $=$ article $\& \mathrm{id}=224 \&$ Itemid=224 (дата обращения: 01.06.2016).
15. Ткачев В. Н. Опытная модель ювенальной юстиции в Ростовской области и ее распространение в регионах России. URL: http:// www.rostoblsud.ru/to_3524582 (дата обращения: 01.12.2016).

16. Bazemore G., Schiff M. Community Justice/Restorative Justice: Prospects for a New Social Ecology for Community Corrections // International Journal of Comparative and Applied Criminal Justice. 1996. Issue 20(2). P. 311-334.

17. Bazemore G., Umbreit M. A Comparison of Four Restorative Conferencing Models. U.S. Department of Justice Office of Justice Programs Office of Juvenile Justice and Delinquency Prevention. February 2001. URL: https://www.ncjrs.gov/pdffiles1/ojjdp/184738. pdf (дата обращения 01.12.2016)

18. Bazemore G., Umbreit M. Rethinking the Sanctioning Function In Juvenile Court: Retribution or Restorative Responses to Youth Crime // Crime and Delinquency. 1995. Issue 41(3). URL: https://www.researchgate.net/publication/ 249718602_Rethinking_the_Sanctioning_Function_in_Juvenile_Court_Retributive_or_Restorative_Response_to_Youth_Crime (дата обращения: 01.12.2016).

19. Braithwaite J. Restorative Justice \& Responsive Regulation. 2002. Oxford University Press, at 249. URL: http://johnbraithwaite.com/wpcontent/uploads/2016/06/Restorative-Justice-andRespon.pdf (дата обращения: 01.12.2016).

20. Feld B. The Punitive Juvenile Court and the Quality of Procedural Justice: Disjunctions between Rhetoric and Reality // Crime \& Delinquency 1990. Issue 36. Pp. 443-466.

21. Gehm J.R. Victim-Offender Mediation Programs: An Exploration of Practice and Theoretical Frameworks // Western Criminology Review. 1998. Issue 1(1). URL: http://wcr.sonoma.edu/v1nl/gehm.html. (дата обращения: 01.06.2016)

22. Griffiths $J$. Ideology in Criminal Procedure or a Third "Model" of the Criminal Process // Yale Law Journal. 1970. Vol. 79. P. 359-417.

23. Hudson J., Morris A., Maxwell G., Galaway B. Family Group Conferences: Perspectives on Policy and Practice. Monsey, N. Y.: Criminal Justice Press, 1996. 240 p.

24. Maxwell G., Morris A. Family, Victims and Culture: Youth Justice in New Zealand. Wellington, NZ: Social Policy. 1993. URL: https:// www.msd.govt.nz/documents/about-msd-andour-work/publications-resources/archive/1993- 
family-victims-and-culture.pdf (дата обращения: 01.06.2016).

25. McAnany P. D., Thompson D., Fogel D. Probation and Justice: Reconsideration of Mission. Cambridge, MA: Oelgeschlager, Gunn \& Hain, 1984. $408 \mathrm{p}$.

26. Melton G. Taking Gault Seriously: Toward a New Juvenile Court // Nebraska Law Review. 1989. Issue 68, P. 146-181.

27. Miller J. Lost One Over the Wall; The Massachusetts Experiment in Closing Reform Schools. Columbus, OH: Ohio State University Press, 1991. $279 \mathrm{p}$.

28. Restorative Justice. URL http://www.answers. com/topic/restorative-justice (дата обращения: 01.03.2013).

29. Restorative Justice: How it Works / Marian Liebmann. Publisher: Jessica Kingsley Publishers. 15 April 2007. P. 472.

30. Restorative Justice: the Government's Strategy July 2003. Response by Victim Support. URL: http://www.restorativejustice.org.uk/assets/_ugc/ fetch.php?file $=\mathrm{c} 3 \mathrm{kp} \_$Restorative_justice_the governments_strategy_response_of_victim_support.pdf (дата обращения: 01.06.2016).

31. Rothman D. Conscience and Convenience // The Asylum and its Alternatives in Progressive America. N. Y.: HarperCollins, 1980. 469 p.
32. Schneider A. Deterrence and Juvenile Crime: Results from a National Policy Experiment. N. Y.: Springer-Verlag, 1990. 127 p.

33. Umbreit M., Zehr H. Agency and Institute of Criminology, Victoria University of Wellington. Family Group Conferences: A Challenge to Victim-Offender Mediation? // VOMA Quarterly. 1995-1996. Issue 7. P. 4-8.

34. Umbreit M. S. Restorative Justice Through Victim-Offender Mediation: A Multi-Site Assessment // Western Criminology Review. 1998. URL: http://wcr.sonoma.edu/v1n1/umbreit.html (дата обращения: 01.03.2013).

35. Walgrave L. Restorative Justice for Juveniles: Just a Technique or a Fully Fledged Alternative? // Howard Journal of Criminal Justice. 1995. Issue 34(3). Pp. 228-249.

36. Whyt $J$. How Do You Mediate a Criminal Case? // The American Bar Association Criminal Justice Section Newsletter. Vol. 15. Issue 1. Fall 2006. URL: http://www.americanbar.org/content/dam/aba/publishing/criminal_ justice_section_newsetter/crimjust_newsletterfall2006.authcheckdam.pdf (дата обращения: 01.06.2016).

37. Zehr H. Changing Lenses: A New Focus for Crime and Justice. Scottsdale, PA: Herald Press, 1990. $271 \mathrm{p}$. 